\title{
JUNIOR HIGH SCHOOL STUDENTS' CRITICAL THINKING SKILLS BASED ON SELF-RELIANCE LEARNING
}

\author{
Gunawan ${ }^{1}$, Irfan Saeful Hidayat ${ }^{2}$, Lukmanul Akhsani ${ }^{3}$, Indira Pipit Miranti ${ }^{4}$ \\ ${ }^{123}$ Universitas Muhammadiyah Purwokerto, Jalan K.H. Ahmad Dahlan Kembaran Purwokerto Jawa Tengah, \\ Indonesia \\ ${ }^{4}$ STIKES Ibnu Sina Ajibarang, Wakalbangkong, Pandansari, Kec. Ajibarang, Kabupaten Banyumas, Jawa Tengah, \\ Indonesia \\ e-mail: gun.oge@gmail.com
}

\begin{abstract}
The study aims to describe the students' critical thinking skills reviewed by self-reliance learning. The research methods used are qualitative descriptive. The research subject is a grade VIII A student of SMP Negeri 3 Kalibagor, which amounted to 28 people. Sampling is performed using the purposive sampling technique. In one class, selected two students with the category of self-reliance learned to be seen, three students with the category of self-reliance began to develop, and two students with a category of self-reliance learning culture. Collection of data using polls, tests, interviews, and documentation. The data analysis techniques used include data reduction, data presentation, and drawing concluding. The validation test used is triangulation. The results showed that more than $80 \%$ of the students who had already filled in the learning independence poll included categories began to develop. Students of self-reliance category learning culture have a better critical thinking ability than the students' categories begin to look and start developing. However, students with these three learning self-reliance categories do not master the evaluation capability indicator.
\end{abstract}

Keywords: critical thinking skills, self-reliance learning, junior high school students

\begin{abstract}
Abstrak
Penelitian ini bertujuan untuk mendeskripsikan kemampuan berpikir kritis siswa ditinjau dari kemandirian belajar. Metode penelitian yang digunakan adalah deskriptif kualitatif. Subjek penelitian adalah siswa kelas VIII A SMP Negeri 3 Kalibagor yang berjumlah 28 orang. Pengambilan sampel dilakukan menggunakan teknik purposive sampling. Dalam satu kelas, dipilih 2 siswa dengan kategori kemandirian belajar mulai terlihat, 3 siswa dengan kategori kemandirian belajar mulai berkembang, dan 2 siswa dengan kategori kemandirian belajar membudaya. Pengumpulan data menggunakan angket, tes, wawancara, dan dokumentasi. Teknik analisis data yang digunakan meliputi reduksi data, penyajian data, dan menarik kesimpulan. Uji validasi yang digunakan adalah triangulasi. Hasil penelitian menunjukkan bahwa siswa dengan kategori kemandirian belajar membudaya memiliki kemampuan berfikir kritis yang lebih baik dibandingkan dengan siswa kategori mulai terlihat dan mulai berkembang. Namun, siswa dengan ketiga kategori kemandirian belajar tersebut tidak menguasai indikator kemampuan mengevaluasi.
\end{abstract}

Kata kunci: kemampuan berpikir kritis, kemandirian belajar, siswa SMP

\section{INTRODUCTION}

Mathematics is one of the subjects that compulsory in schools. Mathematics is a universal science that underlies modern technology development, has an essential role in various disciplines, and advances human thinking (Kristihana \& Ratu, 2018). To know the critical role of mathematics in everyday life, teachers must convey concepts correctly in carrying out learning. Mathematics learning aims to help students gain essential knowledge and lead to achieve several mathematical abilities, and one of them is the ability to think 
critically in mathematics learning. Moreover, currently, Indonesia is implementing the 2013 Curriculum, which one of the goals is to produce students with critical thinking skills. Critical thinking is one of the goals in learning mathematics (Kristihana \& Ratu, 2018).

Critical thinking is needed in mathematics learning because mathematics is about learning concepts and needs to develop additional skills, namely observation, analysis, reasoning, and persuasion (Cottrell, 2005). Critical thinking is widely seen as a basic competency, such as reading and writing, which must be taught (Rohmat \& Lestari, 2019). Critical thinking is a skill that uses logic. Logic is a way of thinking to get knowledge using assessment accompanied by specific patterns of reasoning. By thinking critically, a person can organize, adjust, change, or correct his thoughts to make decisions to act more appropriately (Lestari, Nindiasari, \& Fatah, 2019).

A person's ability to think critically can be identified from the behavior he displays during the thought process. To find out someone's critical thinking ability, we can connect it with the indicators of critical thinking put forward by experts. (Filsaime, 2008) suggests six critical thinking abilities, namely: (1) Interpretation, namely the ability to understand, explain and give meaning to data or information, (2) Analysis, namely the ability to identify relationships from information used to express thoughts or opinions, (3) Evaluation, namely the ability to test the truth of the information used in expressing thoughts or opinions, (4) Inference, namely the ability to identify and obtain the elements needed to make a reasonable conclusion, (5) Explanation, namely the ability to explain or state ideas based on evidence, methodology, and context. (6) Self-regulation, namely a person's ability to regulate his thinking.

There are five systematic behaviors in critical thinking. The five behaviors are as follows: (1) Analysis skills, namely the skills to decipher a structure into components in order to know the organization of the structure, (2) Synthesis skills, skills to combine parts into a new arrangement, (3) Familiar skills and solving problems, namely the ability to apply concepts to several definitions, (4) Conclusion skills, namely the activities of the human mind based on the understanding/knowledge they have to achieve new understanding, (5) Evaluating / judging skills, namely the ability to determine the value of something based on specific criteria (Santoso, 2009). The indicators used in this research are the five skills described above. Critical thinking allows students to study problems systematically, face millions of challenges in an 
organized way, formulate innovative questions, and design problems that are considered relatively new (Hidayat, 2012).

Critical thinking is logical or reasonable thinking that focuses on making decisions about what someone believes and does (Amir, 2015). Critical thinking is the goal of correcting conclusions and making wise choices or decisions (Moore \& Parker, 2009). Critical thinking is an activity through thinking about ideas or ideas related to the concepts given or the problems described (Susanto, 2013).

Students' mathematical problems are not only thinking but also to maximize learning outcomes are also influenced by several aspects, and one of them is learning independence. One of the attitudes that must be possessed to be able to deal with changing circumstances is independence. As a high school student, this independence can take the form of selfreliance learning. Self-reliance learning is a must and a demand in education today. Selfreliance learning is defined as a learning process that occurs in a person, and to achieve learning goals, that person is required to be active individually or not to depend on others, including not depending on his teacher (Suhendri, 2015). (Isnaeni, Fajriyah, Risky, Purwasih, \& Hidayat, 2018) suggest that self-reliance learning is a process of careful self-design monitoring of cognitive and affective processes in completing an academic task, as well as students who have self-reliance learning tall tend to be better at their supervision, able to monitor, evaluate, and organize their learning effectively, save time in completing their tasks, and manage learning and time efficiently. Self-reliance learning is when students control the learning process themselves and the learning objectives (Sundayana, 2016). There are eight characteristics of independent learning, namely being able to think critically, creatively, and innovatively, not being easily influenced by other people's opinions, not running away or avoiding problems, solving problems by thinking deeply, if someone encounter problems he/she will solve them without asking for help from others, no feel inferior if they have to be different from others, try to work with full diligence and discipline and are responsible for their own actions (Sundayana, 2016). The criteria for self-reliance learning expressed by (Prayitno \& Widyanti., 2011) used in this study were BT (not yet seen), MT (beginning to be seen), MB (beginning to develop), and MK (culture). The level of student self-reliance learning can be determined based on how much initiative and responsibility of students to play an active role in learning planning, the learning process, and learning evaluation. If the more self- 
reliance in learning, the more optimal the results of learning mathematics, the more student knowledge can be increased. It is in line with research (Syahbana, 2012), which states that there are significant differences in the improvement of mathematical critical thinking skills between students at high, medium, and low levels of initial mathematics knowledge.

If we see the benefits of critical thinking skills, students should be more motivated to develop these abilities in various ways by improving their learning independence. Students' success in developing critical thinking skills can be achieved by providing awareness to students of self-reliance learning.

\section{METHODS}

This research will be conducted at SMP Negeri 3 Kalibagor in the even semester of 2018/2019. This research type is descriptive qualitative with variables, namely the ability to think critically of students and use a review of independent learning. The method used in this research is a qualitative method with descriptive data analysis. The data analysis technique used is data reduction, data presentation, and conclusions. This research will be conducted at SMP Negeri 3 Kalibagor with the material of a flat-sided building. The research subjects selected in this study were students of SMP Negeri 3 Kalibagor. The technique used is purposive sampling, namely taking the sample, which is the research subject based on certain considerations and goals (Sugiyono, 2013). The considerations used in this study were students who had independent learning mathematics, which was BT (Not Seen), MT (Beginning to Be Visible), MB (Starting to Develop), and MK (Cultivating) using a self-reliance learning questionnaire. The following is the conclusion of the self-reliance learning questionnaire.

Table 1. Criteria for Concluding The Results of The Self-Reliance Learning Questionnaire

\begin{tabular}{lcl}
\hline No & Score & \\
\hline 1 & $1-30$ & Students have yet to show signs of self-reliance in learning (BT) \\
2 & $31-60$ & Students have started to show early signs of self-reliance learning (MT) \\
3 & $61-90$ & $\begin{array}{l}\text { Students have started to show the development of self-reliance } \\
\text { learning (MB) }\end{array}$ \\
4 & $91-120$ & Students have shown their self-reliance in learning (MK)
\end{tabular}

Then, three students will select each category so that the total research sample is 12 people. If there are not filled categories, then the sample used is students taken from the Vol. 5, No. 1, January 2021, 11-22 
remaining self-reliance learning categories. To obtain data and information needed in the study, researchers collected data using data collection techniques according to the research carried out. These data collection techniques were questionnaires, tests, interviews, and documentation. The data analysis used was the Miles and Huberman model. Activities in analyzing data are data reduction, presenting data, and concluding (Sugiyono, 2013). The researcher analyzed the data on the mathematical critical thinking ability test, then rechecked it with an interview. The validation test of the analysis used in this study used the triangulation test. Triangulation is a data collection technique that combines various data collection techniques and existing sources or can be interpreted as a technique to test the validity of data by combining data to measure the data's validity (Sugiyono, 2015: 273). The researcher checked the validity of the data through technical triangulation, namely analyzing the data on the mathematical critical thinking ability test, then checking it again with the interview results.

\section{RESULTS AND DISCUSSION}

Twenty-eight students filled out the self-reliance learning questionnaire. It is obtained, two categories began to appear, 24 categories began to develop, and two categories began to become civilized. It can be concluded that more than $80 \%$ of students are categorized as starting to develop. Then, seven students were selected as research subjects. Taking the research subject used was purposive sampling, namely by looking at the questionnaire results on the self-reliance learning of students and with certain considerations, namely the consideration of class teachers who have good communication and observations. The following is a grouping of self-reliance learning categories presented in Table 2.

Table 2. Grouping of Independent Learning Categories

\begin{tabular}{llcl}
\hline Students & Score & Category & Subject \\
\hline LP & 50 & MT & MT1 \\
FSW & 50 & & MT2 \\
MN & 63 & MB & \\
ACW & 65 & & \\
AEY & 65 & & \\
YS & 65 & & \\
TR & 67 & & \\
SNK & 68 & & \\
MBW & 71 & &
\end{tabular}




\begin{tabular}{|c|c|c|c|}
\hline MAK & 72 & & \\
\hline AEP & 73 & & \\
\hline HFK & 74 & & \\
\hline OR & 74 & & \\
\hline MAP & 75 & & \\
\hline SA & 75 & & \\
\hline AGA & 76 & & \\
\hline DGS & 77 & & \\
\hline $\mathrm{RF}$ & 77 & & \\
\hline HSN & 78 & & \\
\hline SNB & 78 & & MB1 \\
\hline MDS & 79 & & \\
\hline NS & 79 & & \\
\hline GP & 84 & & \\
\hline AM & 89 & & MB2 \\
\hline AIM & 90 & & \\
\hline HKD & 90 & & MB3 \\
\hline $\mathrm{RR}$ & 93 & MK & MK1 \\
\hline VTA & 93 & & MK2 \\
\hline
\end{tabular}

\section{Notes:}

MT1: Subject begins to appear 1, MT2: Subject begins to appear 2, MB1: Subject begins to develop 1, MB2: Subject begins to develop 2, MB3: Subject begins to develop 3, MK1: Subject is cultivating 1, and MB2: Subject is cultivating 2.

The researcher gives 4 questions with cube and cuboid material. The indicators used in this research are the five skills proposed by (Santoso, 2009), including analyzing, synthesizing, solving problems, concluding, and evaluating/evaluating. One of the questions given is as follows.

Pak Rahmat hendak membuat kerangka balok dari kawat, dengan ukuran $11 \mathrm{~cm} \mathrm{x} 12 \mathrm{~cm}$ x $13 \mathrm{~cm}$. Sebelumnya telah membeli kawat sepanjang 45 m dengan harga Rp 90.000,- Berapa banyak balok yang dapat di buat dengan bahan kawat tersebut dan sisa kawat yang tak terpakai?

Figure 1. Critical Thinking Ability Test Questions 
Following are the results of the analysis of students' critical thinking skills in terms of self-reliance learning.

\section{The Self-reliance Learning Category Begins to Appear}

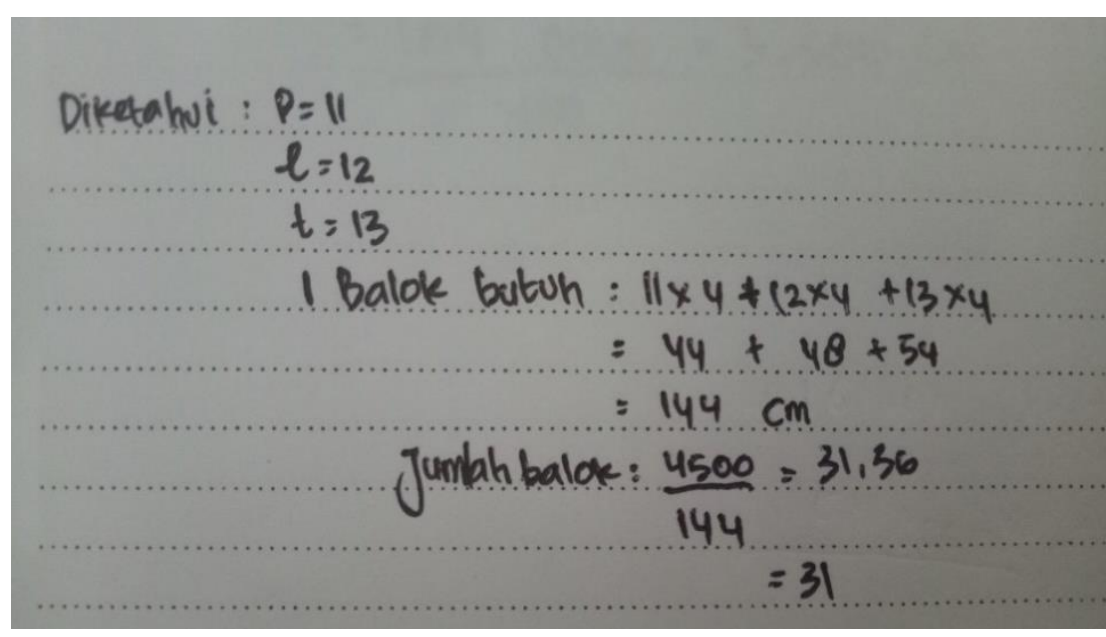

Figure 2. Category Subject Answers Begin to Appear

Two subjects with the visible category have poor critical thinking skills. For the ability to analyze, this is a skill to describe a structure into components that are intended to determine the organization of the problems presented in the questions. The category students began to appear unable to master the indicators of the ability to analyze well. It can be seen from how to answer students in the category of learning independence, which begins to be seen by answering every question asked by the researcher. They are less able to describe what information is contained in a problem structure in the questions used in solving the problem. The category students began to look less able to master the ability to synthesize indicators, and this can be seen from how students with the self-reliance learning category began to appear to answer the questions given and the questions asked by the researcher. They are less able to explain well the pattern of solutions used by linking the information found in the problem with ideal conditions. The category students began to look less able to master the problem-solving indicators. It can be seen in the solutions expressed by students, the category of self-reliance learning is starting to appear that still meets a miss concept so that the problem solving presented will be wrong. Category students began to appear unable to master the ability to conclude indicators. It can be seen in the problem solving presented. There is no defined stage of thinking to conclude and not correctly explain the questions posed by researchers regarding the ability to conclude contained in the questions presented. 
The category students began to appear unable to master the evaluation ability indicators. This can be seen in the problem solving, which is presented without defining a stage of thinking to evaluate.

\section{Self-reliance Learning Category Starts to Develop}

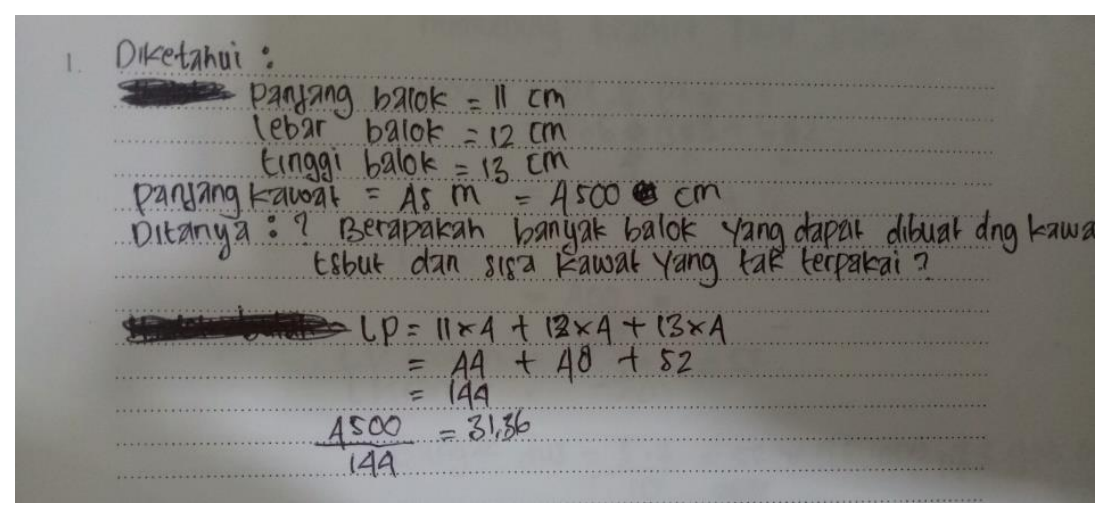

Figure 3. Subject's Answer Begin to Develop

Students with the self-reliance learning category begin to develop and have critical thinking skills starting to lead well. It is shown by providing answers to problems quite well on the questions provided, and they are sufficiently able to master indicators of critical thinking skills, namely the ability to analyze, the ability to synthesize, the ability to solve problems, but still not able to master the ability to conclude and the ability to evaluate.

The first critical thinking ability is the ability to analyze. Students in the developing category have been able to master the indicators of the ability to analyze well. It can be seen from how to answer students. The self-reliance learning category begins to develop by answering every question asked by the researcher. They can describe what information is contained in a problem structure in the questions used in solving the problem.

Students in the category of starting to develop can master the indicators of the ability to synthesize. It can be seen from how students with the category of self-reliance learning begin to develop to answer the questions given and the questions raised by the researcher. They can explain the pattern of solutions used by connecting the information found in the problem with ideal conditions.

Students with categories starting to develop sufficiently have mastered indicators of solving problems. It can be seen in the solutions expressed by students, the category of selfreliance learning has begun to develop, which is already good. However, some problems still have not reached a value even though the concept used to solve the problem is correct. 
Students in the developing category are unable to master the ability to conclude indicators. It can be seen in the problem solving presented by only one respondent who tries to conclude from an answer. However, some still experience errors. The rest do not define a stage of thinking to conclude that students begin to develop and cannot correctly explain the questions raised by researchers regarding the ability to conclude contained in the questions presented.

Students in the developing category are unable to master the indicators of evaluation ability. It can be seen in the problem solving presented there is no defined stage of thinking to evaluate a value by students; the category of self-reliance learning begins to develop. It cannot adequately explain the questions posed by researchers regarding the ability to evaluate contained in the questions presented.

\section{Cultured Self-reliance Learning Category}

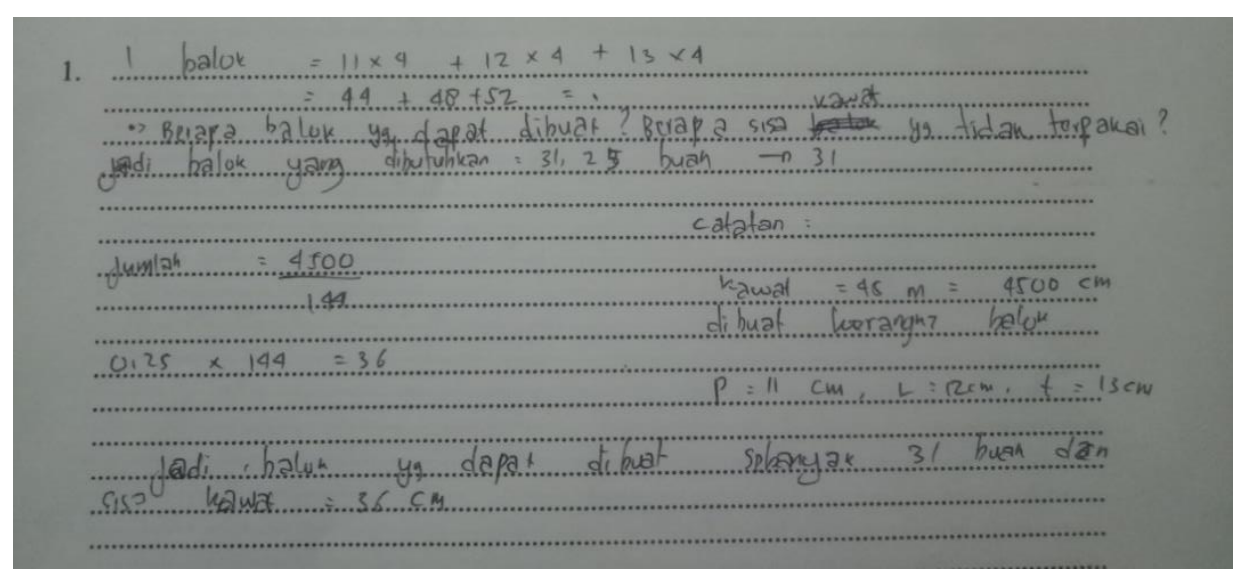

Figure 4. The Subject's Answer Start to Culture

Students with the cultural category have good critical thinking skills. It is shown by Figure 4; namely, they can master indicators of critical thinking skills, namely the ability to analyze, the ability to synthesize, the ability to solve problems, the ability to conclude, but one respondent has not mastered the ability to evaluate.

The first critical thinking ability is the ability to analyze. Students in the independent learning category began to appear unable to master the indicators of ability to analyze well. It can be seen from how to answer students in self-reliance learning, which begins to be seen by answering every question asked by the researcher. They are less able to describe what information is contained in a problem structure in the questions used in solving the problem. 
Students in the cultural independence category of learning can master the indicators of the ability to synthesize. It can be seen from how students with the independence of cultural learning category answer the questions given and the researcher's questions. They can explain the pattern of solutions used by connecting the information found in the problem with ideal conditions.

Students in the cultural category can master this indicator. It can be seen in the solutions expressed by students in the independent learning culture category that is already good. However, some problems still have not reached a value even though the concept used in solving the problem is correct.

Students in the cultural independence category of learning can master the indicators of ability to conclude. It can be seen in solving the problems presented by identifying the existence of a stage of thinking to conclude from the students a good cultural self-reliance learning category and explaining well the questions posed by researchers regarding the ability to conclude contained in the questions presented. The next ability that cannot be measured in this answer is the ability to evaluate, because this stage is not found in the answers presented by the subject.

\section{CONCLUSION}

Based on the results of the discussion that has been described regarding the description of critical thinking skills in terms of self-reliance learning in the material of flat-sided cube and cuboid for students of SMP Negeri 3 Kalibagor, it can be concluded that: 1) More than $80 \%$ of students are included in the category of developing,) Students with self-reliance learning culture category have the ability to think critically better than the category students begin to look and begin to develop, 3) The category students begin to look, begin to develop, and have a culture, each of which has not mastered the indicators of evaluation ability. Suggestions for further research: It is necessary to make learning media that can foster students' critical thinking and use other reviews such as student learning styles that can then be searched for the correlation of the three.

\section{REFERENCES}

Amir, M. F. (2015). Proses Berpikir Kritis Siswa Sekolah Dasar Dalam Memecahkan Masalah Berbentuk Soal Cerita Matematika Berdasarkan Gaya Belajar. Jurnal Math Educator 
Nusantara: Wahana Publikasi Karya Tulis IImiah Di Bidang Pendidikan Matematika, 1(2), 159-170. Retrieved from https://ojs.unpkediri.ac.id/index.php/matematika/article/view/235

Cottrell, S. (2005). Critical Thinking Skill: Developing Effective Analysis and Argument. New York: Palgrave Macmillan.

Filsaime, D. K. (2008). Menguak Rahasia Berpikir Kritis dan Kreatif. Jakarta: Prestasi Pustaka. Hidayat, W. (2012). Meningkatkan Kemampuan Berpikir Kritis dan Kreatif Matematik Siswa SMA Melalui Pembelajaran Kooperatif Think-Talk-Write (TTW). In Seminar Nasional Penelitian, Pendidikan dan Penerapan MIPA. Yogyakarta: Universitas Negeri Yogyakarta.

Isnaeni, S., Fajriyah, L., Risky, E. S., Purwasih, R., \& Hidayat, W. (2018). Analisis Kemampuan Penalaran Matematis Dan Kemandirian Belajar Siswa SMP Pada Materi Persamaan Garis Lurus. Journal of Medives: Journal of Mathematics Education IKIP Veteran Semarang, 2(1), 107-116. Retrieved from http://ejournal.ivet.ac.id/index.php/matematika/article/view/528

Kristihana, O., \& Ratu, N. (2018). Deskripsi Berpikir Kritis Dalam Memecahkan Masalah Bangun Datar Pada Siswa Smp Kelas Viii. Genta Mulia: Jurnal IImiah Pendidikan, 9(2), 150-161. Retrieved from https://ejournal.stkipbbm.ac.id/index.php/gm/article/view/176/164

Lestari, R. B., Nindiasari, H., \& Fatah, A. (2019). Penerapan Pendekatan Metakognitif Untuk Meningkatkan Kemampuan Berpikir Kritis Matematis Siswa Sma Ditinjau Dari Tahap Perkembangan Kognitif. Prima: Jurnal Pendidikan Matematika, 3(2), 134-145. Retrieved from http://jurnal.umt.ac.id/index.php/prima/article/view/1209

Moore, B. N., \& Parker, R. (2009). Critical Thinking. Boston: McGraw-Hill.

Prayitno, E. W., \& Widyanti. (2011). Modul Matematika SMP Program BERMUTU, BPSDMPPMP. PPPPTK Matematika: Kemendiknas.

Rohmat, A. N., \& Lestari, W. (2019). Pengaruh Konsep Diri dan Percaya Diri terhadap Kemampuan Kemampuan Berpikir Kritis Matematis. Jurnal Kajian Pendidikan $\begin{array}{lllll}\text { Matematika } & \text { (JKPM), } & \text { 5(1), } & \text { 73-84. } & \text { Retrieved }\end{array}$ https://journal.Ippmunindra.ac.id/index.php/jkpm/article/view/5173 
Santoso, H. (2009). Pengaruh Penggunaan Laboratorium Riil dan Laboratorium Virtuil pada Pembelajaran Fisika Ditinjau dari Kemampuan Berpikir Kritis Siswa. Universitas Sebelas Maret.

Sugiyono. (2013). Metode Penelitian Pendidikan: Pendekatan Kuantitatif, Kualitatif, dan R \& D. Bandung: Alfabeta.

Suhendri, H. (2015). Pengaruh Metode Pembelajaran Problem Solving Terhadap Hasil Belajar Matematika Ditinjau Dari Kemandirian Belajar. Formatif: Jurnal IImiah Pendidikan MIPA, 3(2), 105-114. Retrieved from https://journal.Ippmunindra.ac.id/index.php/Formatif/article/view/117/114

Sundayana, R. (2016). Kaitan Antara Gaya Belajar, Kemandirian Belajar, Dan Kemampuan Pemecahan Masalah Siswa SMP Dalam Pelajaran Matematika. Mosharafa: Jurnal Pendidikan Matematika, 5(2), 75-84. Retrieved from https://journal.institutpendidikan.ac.id/index.php/mosharafa/article/view/mv5n2_4

Susanto, A. (2013). Teori Belajar Dan Pembelajaran Di Sekolah Dasar. Jakarta: Kencana Prenada Media Group.

Syahbana, A. (2012). Peningkatan Kemampuan Berpikir Kritis Matematis Siswa Smp Melalui Pendekatan Contextual Teaching and Learning. Edumatica: Jurnal Pendidikan Matematika, 2(1), 45-57. Retrieved from https://www.onlinejournal.unja.ac.id/edumatica/article/view/604/538 